\title{
A Review of Technical Standards for Smart Cities
}

\author{
Chun Sing Lai ${ }^{1,2}{ }^{\mathbb{D}}$, Youwei Jia ${ }^{3, *}$, Zhekang Dong ${ }^{4, *}$, Dongxiao Wang ${ }^{5}$, Yingshan Tao ${ }^{2}$ (D), \\ Qi Hong Lai ${ }^{6}$, Richard T. K. Wong ${ }^{7}\left(\mathbb{D}\right.$, Ahmed F. Zobaa ${ }^{1, * \mathbb{D}}$, Ruiheng Wu ${ }^{1}$ and Loi Lei Lai ${ }^{2, *(\mathbb{D})}$
}

1 Department of Electronic and Computer Engineering, Brunel University London, London UB8 3PH, UK; chunsing.lai@brunel.ac.uk (C.S.L.); ruiheng.wu@brunel.ac.uk (R.W.)

2 Department of Electrical Engineering, School of Automation, Guangdong University of Technology, Guangzhou 510006, China; 2111704005@mail2.gdut.edu.cn

3 Department of Electrical and Electronic Engineering, Southern University of Science and Technology, Shenzhen 518055, China

4 School of Electronics and Information, Hangzhou Dianzi University, Hangzhou 310018, China

5 System Design and Engineering Department, Australia Energy Market Operator, Melbourne 3000, Australia; dongxiao.wang@aemo.com.au

6 Sir William Dunn School of Pathology, University of Oxford, Oxford OX1 3RE, UK; qi.lai@path.ox.ac.uk

7 Department of Computing and Information Systems, School of Science and Technology, Sunway University, Selangor 47500, Malaysia; richardwtk@sunway.edu.my

* Correspondence: jiayw@sustech.edu.cn (Y.J.); englishp@hdu.edu.cn (Z.D.); azobaa@ieee.org (A.F.Z.); 1.1.lai@ieee.org (L.L.L.)

Received: 14 June 2020; Accepted: 12 August 2020; Published: 17 August 2020

\begin{abstract}
Smart cities employ technology and data to increase efficiencies, economic development, sustainability, and life quality for citizens in urban areas. Inevitably, clean technologies promote smart cities development including for energy, transportation and health. The smart city concept is ambitious and is being refined with standards. Standards are used to help with regulating how smart cities function and contributing to define a smart city. Smart cities must be officially recognized by national and international authorities and organizations in order to promote societal advancement. There are many research and review articles on smart cities. However, technical standards are seldom discussed in the current literature. This review firstly presents the study of smart city definitions and domain. The well-known smart city standards will be presented to better recognize the smart city concept. Well-defined standards allow meaningful comparisons among smart cities implementation. How smart city initiatives make a city smarter and improve the quality of life will be discussed for various countries. This review highlights that technical standards are important for smart cities implementation. This paper serves as a guide to the most recent developments of smart cities standards.
\end{abstract}

Keywords: smart city; technical standard; smart energy; smart health; smart transportation; smart governance; smart education

\section{Introduction}

By 2050 , it is expected that $66 \%$ of the global population will dwell in urban regions [1]. The challenge will be to supply these populations with essential resources including sufficient energy, clean water, and safe food while simultaneously warranting complete economic, social, and environmental sustainability.

Several cities today have aspirations of transforming into the smart cities of tomorrow. However, the challenges to be overcome to accomplish this include the planning of a complicated plan that comprises public and private participants, product vendors, and information technology infrastructure 
providers. A smart city needs the foundation of standards-based information technology infrastructure that fulfils and supports a wide range of requirements and can adapt to novel technologies, such as advanced sensors, measurement and analytics tools, and solutions driven by machine learning and artificial intelligence. Smart city development requires support from public organizations, citizens, state and local government, and private enterprises. The benefits of a smart city include the creation of major prospects for sustainability, disaster prevention, business, public safety, and quality of life enhancements. However, there are key challenges that need to be addressed for a smart city including:

Commodification: As discussed by Gandy and Nemorin [2], a major concern regarding the smart cities' development is the motivation to support this worldwide initiative, from the pursuit of new markets by transnational corporations. Corporate organizations are keen to mine personal data, such as biometric data [3]. Data brokers could create consumer profiles including biometric information, and identities can be located and tracked as citizens move in a smart city. These profiles can also intensify commodification by mining the freshly available sources of data, with the ubiquity of sensors as dynamic data collection points.

Social and digital exclusion: In designing smart cities solutions, it is important to use suitable means to engage and empower population groups which are hard to reach, such as citizens living in poverty and/or social exclusion, migrants, younger and older people, or people with disabilities [4]. Smart city technologies should be made affordable and able to be accessed by all groups of consumers. A smart city should be an age-friendly environment. The World Health Organization defines age-friendly environments as ones which "foster health and well-being and the participation of people as they age" [5]. These environments are accessible, equitable, inclusive, safe and secure, and supportive. Senior citizens may experience negative attitudes and discrimination based on their age. Creating age-friendly environments acknowledges diversity, fights ageism, and ensures that everyone has the opportunity to fully participate.

Privacy and surveillance: Privacy becomes a major concern when the data collected could lead to linking or identifying an individual, especially when gathered from numerous information sources. Data storage by governments is generally non-transparent. The likelihood for cross-sharing data within government services could lead to third parties to have access to the data, where the provider has no intention for it to happen. Zoonen [6] constructed a four-quadrant privacy framework to theorize if and how smart city technologies and urban big data produce privacy concerns among the people in these cities. The framework is developed according to two recurring dimensions in research towards people's concerns about privacy: one dimension signifies that people see specific data as more personal and sensitive than others, the other dimension signifies that people's privacy concerns vary according to the purpose for which data is gathered, in contrast to the surveillance and service purposes which are the most dominant. The work concludes that the smart technology options and the use of specific data and analytic tools are important factors to comprehend people's privacy concerns in smart cities, as well as to their awareness of what type of data to use to serve a purpose. A smart city should address (1) an applied need to substantiate the empirical relation between purpose, and technologies, and; (2) to produce a theoretical and situated comprehension of people's privacy anxieties in smart cities.

In addition, building a smart city is a gigantic task as there are several working parts and components involved, namely the smart cities domains [7]. Many smart cities are not constructed from scratch or all in a single attempt. Smart city development is a gradually evolving process that witnesses the city becoming smarter, bit by bit. As time progresses, the individual regions of smartness develop together and interconnect, but on the condition for them using the same consistent technical rules that are stipulated by technical standards.

Several researchers have reviewed smart city projects from different perspectives. Camero and Alba [8] explored the computer science and information technology used for a smart city. There is no agreement on a smart city definition and in fact, several definitions are being developed. One explanation is for the iterative process where cities become smarter as time progresses. There are 
very few studies on the inclusion of policy and urban planning recommendations in information technology and computer science literature.

Caird and Hallett [9] examined the creation of appropriate, valid, credible, and valuable approaches to smart city evaluation by studying conceptual, measurement, and evaluation challenges for five UK smart city projects. Caird and Hallett [9] identified that a critical challenge for evaluation design is in creating standardized smart city development and performance indicators that give useful citizen and city-centered evaluations. There is a significant amount of work on standardization and smart urban metrics driven by international standards organizations. Specifically, the Smart and Sustainable Cities and Communities Coordination Group advises on European interests and requirements concerning standardization on Smart and Sustainable cities and communities. The International Organization for Standardization (ISO) has concurred on standards for 'Smart Community Infrastructures' performance metrics. ISO Technical Report 37150:2014 (Smart community infrastructures-Review of existing activities relevant to metrics) [10] reports community infrastructures including water, energy, waste transportation, and Information and Communications Technology (ICT). The standard concentrates on the technical features of current activities which are available. Political, societal, or economic aspects are not studied in this standard. ISO Technical Report 37151:2015 (Smart community infrastructures-Principles and requirements for performance metrics) [11] details the principles and stipulates requirements for the definition, identification, optimization, and harmonization of community infrastructure performance metrics, and gives recommendations for analysis, including smartness, interoperability, synergy, resilience, safety, and security of community infrastructures. Funded by the European Union HORIZON 2020 program, the CITYkeys project [12] is an important European Commission EUROCITIES initiative that aims to create acceptable city performance measurement frameworks: Key Performance Indicators. The initiative creates standardized data collection processes to increase the adoption rate of smart city solutions. It is anticipated that comparable, scalable, and replicable smart city solutions can be achieved across cities. The authors concluded that standardized smart urban metrics and indicators are not widely adopted by cities while the development of standards is at the early stages.

Hasija [13] examined the current global advancements in smart city initiatives. The study was categorized into three themes, namely data access and collection, end-user utility, and economic feasibility of different solutions. The economic viability is crucial to the success of a smart city initiative. The potential ideas to enhance city operations could not be delivered if it they are economically unsustainable. For business strategies, prudent analysis is required to examine the trade-offs that determine the efficacy of such initiatives. A bike-sharing scheme is an affordable and convenient mode of transportation in China. However, not all bike-sharing companies are successful. Some of the issues contribute to the failure of bike-sharing initiatives include (1) no regulation: bikes could end up in different places and be dumped along city streets; (2) lack of operational sustainability: many bike-sharing platforms do not need a security deposit; (3) no optimization: lack of consideration for how and where the bikes should be located to maximize utilization and to avoid bikes piling up on streets.

Anthopoulos [14] examined twenty smart cities projects of various scales in different countries and continents. Furthermore, the review documented the challenges that the cities meet as they work towards being a smart city. The review examines smart cities in relation to climate change, sustainability, natural disasters, and community resiliency. A smart city project is complex and expensive. Anthopoulous [14] firstly examined the project management guidelines and frameworks for agile and complex projects, including a smart city. ISO 21500:2012 Guidance on project management is an international standard that can be used by private or public organizations for all kinds of projects. The aim is to provide a guide to project managers on how to apply project management disciplines into a business environment to increase the possibilities for enhanced business results and project success. An important aspect is the use of the common language and processes by all project stakeholders, which enhances communication and cooperation. ISO 21500 gives a high-level description of concepts and processes to create good practices in project management. The cities reviewed focuses on the project management perspective including scope, organization, time, cost, 
quality, risk, and procurement. The smart city projects are well documented with great detail in the project development. However, there is a lack of discussion on technical standards of the smart city projects apart from project management.

Van Winden and Van den Buuse [15] analyzed the procedures of upscaling, concentrating on smart city pilot projects where numerous stakeholders with dissimilar missions, agendas, and incentives work together. If technical standards can be smoothly adapted to fit with the geospatial context, then the solution becomes more attractive to many cities. Numerous works on smart cities have been conducted and review literature for smart cities exists. However, most recent literature lacks discussions on an important topic of international standards for smart cities. International standards are technical standards developed by international organizations. International standards can greatly assist tailor-made solutions development for bespoke conditions of a city. Standards stipulate the anticipated level of performance and technologies compatibility. Standards are generic metrics that allow solutions to be benchmarked and compared. Section 2 presents the definitions and domains of smart cities. As international standards are the basis of building a smart city, Section 3 exhibits international standards for a smart city. Section 4 describes the current smart city projects for various countries and the standards adopted. The conclusion is given in Section 5.

\section{Smart City Definitions and Domains}

One of the reasons behind the lack of unified definitions of a smart city is because of the various entities involved and the functions the smart city provides. Hence, existing definitions can vary greatly. There are several definitions for a smart city which are defined by various organizations and stakeholders.

The most common consensus is that the smart city employs various kinds of digital and electronic technologies to transform the living environments with ICTs [16,17]. Deakin [18] labeled the smart city as a city that employs ICT to meet the market (the citizens') needs. There is a need for larger community involvement to achieve a smart city. A smart city does not simply contain ICT technology but has also developed the technology to achieve positive impacts to the local community. Some definitions for a smart city from major professional organizations and government agencies are given as follows:

- Association of Southeast Asian Nations [19]: “A smart city in ASEAN harnesses technological and digital solutions as well as innovative non-technological means to address urban challenges, continuously improving people's lives and creating new opportunities. A smart city is also equivalent to a "smart sustainable city", promoting economic and social development alongside environmental protection through effective mechanisms to meet the current and future challenges of its people, while leaving no one behind. As a city's nature remains an important foundation of its economic development and competitive advantage, smart city development should also be designed in accordance with its natural characteristics and potentials".

- British Standard Institution [20]: A smart city is an "effective integration of physical, digital and human systems in the built environment to deliver a sustainable, prosperous and inclusive future for its citizens".

- Department for Business, Innovation and Skills, UK [21]: “A Smart City should enable every citizen to engage with all the services on offer, public as well as private, in a way best suited to his or her needs. It brings together hard infrastructure, social capital including local skills and community institutions, and (digital) technologies to fuel sustainable economic development and provide an attractive environment for all".

- European Commission [22]: "A smart city is a place where traditional networks and services are made more efficient with the use of digital and telecommunication technologies for the benefit of its inhabitants and business. A smart city goes beyond the use of ICT for better resource use and less emissions. It means smarter urban transport networks, upgraded water supply and waste disposal facilities and more efficient ways to light and heat buildings. It also means a more 
interactive and responsive city administration, safer public spaces and meeting the needs of an ageing population".

- Innovation and Technology Bureau, Hong Kong [23]: "Embrace innovation and technology to build a world-famed Smart Hong Kong characterised by a strong economy and high quality of living".

- Institute of Electrical and Electronics Engineers Smart Cities Community [24]: A smart city gathers government, technology, and society to achieve a minimum of the following factors: smart mobility, a smart economy, a smart environment, smart cities, smart governance, smart people, and smart living.

- International Electrotechnical Commission [25]: "A smart city is one where the individual city systems are managed in a more integrated and coherent way, through the use of new technologies and specifically through the increasing availability of data and the way that this can provide solid evidence for good decision making".

- Japan Smart Community Alliance [26]: The expression "Smart Community" is more widespread than "Smart City" in Japan [22]. "A smart community is a community where various next-generation technologies and advanced social systems are effectively integrated and utilized, including the efficient use of energy, utilization of heat and unused energy sources, improvement of local transportation systems and transformation of the everyday lives of citizens".

- Ministry of Housing and Urban Affairs, India [27]: "The conceptualisation of Smart City, therefore, varies from city to city and country to country, depending on the level of development, willingness to change and reform, resources and aspirations of the city residents. A smart city would have a different connotation in India than, say, Europe. Even in India, there is no one way of defining a smart city".

According to the above, the similarity and differences in smart city definitions can be summarized as follows:

- $\quad$ Similarities:

$\bigcirc \quad$ Enhancement of living standards by making informed decisions with advanced technologies to collect, process, and evaluate data.

$0 \quad$ Systems are integrated to exchange information.

Citizens are better informed about their surroundings.

Sustainability and environmental conservation should be maximized.

- Differences:

- Smart city domains or elements e.g., transport, energy, and health (explained in the following section) can be different due to regional interests.

From the above summary, it is shown that for a city to become smart, multiple sources of data from a range of urban activities and domains must be connected to reveal opportunities to bring innovation to today's connected citizens. Deloitte [28] stated that a smart city is driven by the innovation success of six key domains including:

1. Energy and environment: Sustainable growth is created by technology and cities make better use of resources from electronic sensors that monitor leakages, as well as gamification and behavioral economics to support citizens to conduct considerate decisions on resource utilization [29]. Renewable energy including solar and wind will be important sources of energy generation [30-32]. Data analytics will be used to enhance energy and power system operation [33];

2. Economy: The economy will be affected by digitization and disruptive technologies, which will change the needs of several types of jobs. Smart cities need to create strategies to adopt future jobs that will power Industry 4.0 and beyond [34]; 
3. Safety and security: As criminals will make use of technology to commit advanced crimes, public safety and security authorities will also use technology for crime prevention by assessing multiple streams of social and crowdsourced information, including super-resolution images [35] and image fusion [36];

4. Health and living: The lives of citizens are enhanced with technology and connectivity. Connected communities are achieved with smart buildings. Enhanced social programs and innovated health care sector are data-driven [37];

5. Mobility: The integrated mobility systems include autonomous vehicles and shared mobility services achieved with the Internet of Things (IoTs). The concept of IoTs occurs when devices are communicating with other devices on behalf of people and will dominate the future of Internet communications [38]. Advanced analytics allow citizens and goods to travel in ways that are safer, cheaper, cleaner, and faster [39];

6. Education and government: Technological advancement will aid government procedures and give a seamless experience to businesses. Smart cities use analytics to assist authorities to create insight-driven policies, monitor performance and outcomes, allow constituent engagement, and enhance government efficiency. Data and analytics will also assist next-generation teachers to familiarize their counselling and teaching for greater student achievement. More creative and personalized education plans can be created such as virtual learning environments [40].

Similarly, Giffinger et al. [41] described the smart city as having six domains, including:

1. Smart economy: Consists of features surrounding economic competitiveness including entrepreneurship, innovation, flexibility, the productivity of the labour market, trademarks, and participation in the global market.

2. Smart people: Concerns not only the level of qualification or education received by citizens but also additional social interactions and perceptions of public life.

3. Smart governance: Concerns political involvement, citizen services, and administration functions.

4. Smart mobility: Includes local and global accessibility with the presence of ICTs and sustainable and relevant transport systems.

5. Smart environment: Concerns attractive natural conditions including green space, less extreme climate, reduced pollution, resource management, and working to achieve environmental protections.

6. Smart living: Includes many features of quality of life composed of health, housing, culture, tourism, and safety.

It is worth noting that there are other domains including:

Smart water [42,43]: Smart water systems employ IoT enabled sensors to collate real-time data. With precise and reliable data, smart water systems can drive great transformations in water sector transparency and accountability. There will be governance improvements, risk reductions, water quality control and eventually a novel business cases for water sector investment [43]. The data allows water facilities optimization by detecting leaks or observing how water is distributed in the water network. The optimization model empowers citizens to make better decisions about water management. Smart sensors can detect water pipe leaks and quickly inform engineers to take action and resolve the issue. Smart water is critical as an estimated 3.3 billion litres of water is wasted daily in Wales and England due to leaks in water networks [42].

Smart health [44,45]: The European Commission [44] described smart health permits healthcare providers to reduce illnesses occurrence, to care for patients more efficiently, and to cure illnesses more effectively. Smart health also reduces healthcare expenditure in the growing aging population. Smart health solutions consist of technological developments in portable and mobile devices, sensor technology, application development, mobile data connectivity, cloud computing, and big data analytics, with new ideas on patient co-management, health tracking of remote neighborhoods, 
and minimizing unhealthy lifestyles. Deloitte [45] stated that smart health consists of five features, including to: (1) empower proactive health and well-being management to make choices that can proactively improve health, well-being, and quality of life to reduce adverse health outcomes in the future; (2) foster a sense of community and well-being with virtual and in-person community meetings; (3) enable digital technology and behavioral science with mobile applications for users to enter and track data and seek information, e.g., fitness tips and recipes, and deploy the use of coaching and guide to support adherence and uptake of behaviors associated with healthy, active living; (4) meaningfully use data to improve outcomes and allow users to track their progress. Consent would be requested from users to share and use data, to enhance the program and for it to make improved recommendations; (5) enable new and innovative ecosystems to consist of the collaboration of businesses with all kinds of organizations e.g., government agencies and academia to align on health outcome measures and coordinate on investments in communities.

Smart waste [46,47]: Interreg Europe [47] described smart waste as being used "to improve public policy instruments supporting innovation within waste management procedures. The final result? Smarter, more effective, sustainable, and cost-efficient waste management, benefiting all territorial stakeholders". In the UK, illegal waste activity including fly-tipping costs the UK economy approximately $£ 600 \mathrm{M}$ annually [46]. The present systems for monitoring commercial and household waste are out-of-date and mainly paper-based. Smart waste employs technology including blockchain [48], electronic chips, and sensors for monitoring waste, waste containers, and waste vehicles. Smart waste is an element of smart living and smart environments.

In summary, a smart city is an ambitious and crucial transformation of many cities worldwide. Benefits include improved living conditions are reaped from several sectors/domains. However, a smart city consists of the development and application of novel technologies. There is a need for standardized uniform engineering or technical criteria, methods, processes, and practices. The next section examines how international standards help to build a smart city.

\section{International Standards for Smart City}

The International Organization for Standardization (ISO) has described standards as "the first step towards the holy grail of an interoperable, plug-and-play world where cities can mix and match solutions from different vendors without fear of lock-in or obsolescence or dead-end initiatives" [49]. International standards are best practice created by global experts. Standards can be used to benchmark functional and technical performances. Standards make sure that technologies deployed in cities are efficient, safe, and well-integrated.

The largest and most well-established international standards organizations include ISO [50], the International Electrotechnical Commission (IEC) [51], and the International Telecommunication Union (ITU) [52] which were founded between 50 and 150 years ago. The description of these organizations are as follows:

- ISO is a non-governmental and independent global organization with 164 national standards bodies as members. The standards body for each country (e.g., Bureau de Normalisation (NBN) in Belgium and Ghana Standards Authority (GSA) in Ghana) works directly with ISO and aims to minimize diversity in technical definitions. ISO standards are applied in various fields including quality management, environmental management, IT security, energy management, health and safety, and food safety [50].

- IEC is the world's forefront organization for the groundwork and publication of international standards for electronic, electrical, and relevant technologies, i.e., "electrotechnology" [51]. IEC described technical and international standards as reflecting "agreements on the technical description of the characteristics to be fulfilled by the product, system, service or object in question. They are widely adopted at the regional or national level and are applied by manufacturers, trade organizations, purchasers, consumers, testing laboratories, governments, regulators and other interested parties". Standards help researchers, industry, regulators, and consumers globally 
to achieve an optimal experience and meet mutual needs for various countries. Standards establish one of the vital bases for the elimination of technical obstacles to trade.

- ITU is the United Nations bespoke agency for ICTs and enables global connectivity of communications networks [52]. ITU manages international satellite orbits and radio spectrum, creates the international standards that allow technologies and networks to be continuously interconnected, and aims to enhance ICT access for global communities.

The above organizations have developed standards to specify and establish definitions and methodologies for a set of smart cities indicators. For example, ISO 37122:2019 (Sustainable Cities and Communities-Indicators for Smart Cities) [50] intends to give a holistic set of indicators to evaluate advancement in developing a smart city. The standard includes multiple domains including education, energy, economy, environment and climate change, finance, governance, health, housing, population and social conditions, recreation, safety, solid waste, sport and culture, telecommunication, transportation, urban/local agriculture and food safety, urban planning, wastewater, and water. The World Council on City Data is a prominent initiative in using standardized city data to create smart cities [53]. The initiative hosts a network of innovative cities dedicated to refining quality of life and services with open city data and delivers a reliable and holistic platform for standardized urban metrics. The World Council on City Data is an international hub for international organizations, education partnerships across cities, corporate partners, and academia to expand innovation, envisage alternative futures, and construct enhanced cities. The initiative developed the first city data standards, namely, ISO 37120 (Sustainable development of communities: Indicators for city services and quality of life).

The IEC has identified over 1800 standards that already impact smart cities [54]. The SyC Smart cities promote the coordination of standards efforts of several IEC committees and other organizations, including ISO, to promote the development of standards to achieve integration, interoperability and effectiveness of city systems. SyC Smart City is presently developing IEC 63152 as the best practice tool for city planners. Considering the higher frequency of natural disasters and destruction in some urban areas, IEC 63152 proposes guidelines to sustain several city services after a disruption occurs. IEC 63152 provides the fundamental concepts of how several city services can cooperate to uphold the supply of electricity.

ITU established Study Group 20 and United for Smart Sustainable Cities to develop standard activities in supporting the utilization of ICTs in a smart city [55]. These standards focus on terminologies for the IoTs and smart cities, high performing ICT infrastructures requirements, and the interoperability between various ICT or IoT networks. The ICT standard consists of four layers, namely the "application and support layer", "data layer", "communication layer", and "sensing layer".

In addition to the above three organizations, the Institute of Electrical and Electronics Engineers (IEEE) also develops international standards for smart cities. One of the most well-known IEEE standards is the IEEE 802 family, which was established in the early 1980s and covers local area networks and metropolitan area networks [56]. In recent years, IEEE has established the IEEE Smart Cities Community, which "brings together IEEE's broad array of technical societies and organizations to advance the state of the art for smart city technologies for the benefit of society and to set the global standard in this regard by serving as a neutral broker of information amongst industry, academic, and government stakeholders" [57].

In 2017, the IEEE P2784 (Smart City Planning Guide) [58] was proposed to develop a framework that mentions the processes and technologies for planning the smart city transformation. A smart city requires a unified process planning framework to use IoTs to guarantee agile, interoperable, and scalable solutions that can be used and supported sustainably. The framework is a method for technology and cities integrators to plan for technology and innovative solutions for smart cities. Some of the most recent and first-of-a-kind standard initiatives from IEEE are presented in Tables 1-5. 
Table 1. Recent Institute of Electrical and Electronics Engineers (IEEE) Standards in development for a smart grid and smart energy.

\begin{tabular}{|c|c|c|}
\hline Year & Title & Scope \\
\hline 2016 & $\begin{array}{l}\text { 1889-2018 (Evaluating and Testing the Electrical Performance of Energy } \\
\text { Saving Devices) [59] }\end{array}$ & $\begin{array}{l}\text { - Tests and evaluates energy saving devices' electrical performance. } \\
\text { Measurement methods for observing the power generated or used by the observed load or generator: (1) without the energy saving devices connected to } \\
\text { the circuit; (2) with the energy saving devices connected and powered in the circuit. } \\
\text { Detailed protocols for testing circuits, the accuracy and details of evaluation instrumentation, and the sequence of the test measurements. } \\
\text { - Bespoke details for possible sources of measurement errors including from (1) wrong instrumentation connection, (2) inadequate instrumentation, or (3) } \\
\text { - } \quad \text { rong results interpretation. }\end{array}$ \\
\hline 2016 & $\begin{array}{l}\text { P1922.1 (A Method for Calculating Anticipated Emissions caused by } \\
\text { Virtual Machine Migration and Placement) [60] }\end{array}$ & $\begin{array}{l}\text { - Methods to compute anticipated emissions created by virtual machine migration and allocation in distributed locations created by various } \\
\text { electricity sources. } \\
\text { - Identify the anticipated electric grid's marginal emissions due to the change in power generation capacity, reflected by the additional power demand } \\
\text { from server accepting the virtual machine and the network supporting virtual machine migration. } \\
\text { - Creates a technique to study anticipated gaseous (also greenhouse gases) and particle emissions created by virtual machine migration and allocation in } \\
\text { distributed servers situated in various regions. }\end{array}$ \\
\hline 2019 & $\begin{array}{l}\text { P2814 (Techno-economic Metrics Standard for Hybrid Energy and Storage } \\
\text { Systems) [61] }\end{array}$ & - Techno-economic metrics for operation, construction, and development of electrical energy storage systems and renewable energy systems. \\
\hline 2020 & $\begin{array}{l}\text { P2852 (Intelligent Assessment of Safety Risk for Overhead Transmission } \\
\text { Lines Under Multiple Operating Conditions) [62] }\end{array}$ & $\begin{array}{l}\text { - Artificial intelligence methods for a 3-D model of overhead transmission line and locational surroundings, to achieve a precise perception of overhead } \\
\text { conductors to the ground and near buildings and trees. } \\
\text { - Identifies safety risk information including distance for overhead transmission lines in various operating conditions and provides an intelligent security } \\
\text { assessment technique. } \\
\text { Useful for intelligent evaluation and control overhead transmission lines safety risk during a typhoon, hot weather, icing, and alternative } \\
\text { operating conditions. }\end{array}$ \\
\hline
\end{tabular}


Table 2. Recent IEEE Standards in development for smart health.

\begin{tabular}{|c|c|c|}
\hline Year & Title & Scope \\
\hline 2014 & 1708-2014 (Wearable Cuffless Blood Pressure Measuring Devices) [63] & $\begin{array}{l}\text { - Creates objective performance and normative definition for assessment of wearable cuffless blood pressure measuring devices. } \\
\text { - Works for all forms of the device or the vehicle where the device is attached or where it is embedded. } \\
\text { operation modes. } \\
\text { - Limited to the assessment of devices that do not use a cuff whilst measuring. } \\
\text { No assessment of all sphygmomanometers operated with an inflatable or occluding cuff for the non-intrusive assessment of blood pressure on the upper } \\
\text { wrist or arm. } \\
\text { Manufacturers guidelines to certify and confirm their products, possible purchasers or users to examine and choose potential products, and health care } \\
\text { professionals to perceive the manufacturing practices on wearable blood pressure devices. }\end{array}$ \\
\hline 2017 & $\begin{array}{l}\text { P3333.2.5 (Bio-CAD File Format for Medical Three-Dimensional (3D) } \\
\text { Printing) [64] }\end{array}$ & $\begin{array}{l}\text { Establishes the Bio-Computer Aided Design format for 3-D printing from sectional scan image data comprising of volumetric and surface information } \\
\text { Related to medical 3-D printing services including pathologic services, anatomic models, and medical instrument printing with 2-D images, 3-D medical } \\
\text { data, and alternative medical data. }\end{array}$ \\
\hline 2017 & P1752 (Mobile Health Data) [65] & $\begin{array}{l}\text { - States requirements for mobile health data applications programming interface and standardized representations for mobile metadata and health data. } \\
\text { - Mobile health data consists of personal health data collated from mobile applications and sensors. }\end{array}$ \\
\hline 2019 & 1847-2019 (Common Framework of Location Services for Healthcare) [66] & - The framework consists of location services for healthcare conceptual information model and location services for healthcare common terminology. \\
\hline 2020 & $\begin{array}{l}\text { P2621.1 (Wireless Diabetes Device Security Assurance: Product Security } \\
\text { Evaluation Program) [67] }\end{array}$ & $\begin{array}{l}\text { A connected electronic product security evaluation program framework consists of: } \\
\text { 1. A method to use the ISO/IEC } 15408 \text { security evaluation framework in a security evaluation program. } \\
\text { 2. Allowing independent testing labs for security evaluation program. } \\
\text { 3. Confirming results from authorized labs. } \\
\text { 4. Defining and certifying novel security requirements and adjustments to security requirements, from protection profiles and security targets for } \\
\text { 5. Asurity evaluation program. } \\
\text { Asurance post-certification maintenance. }\end{array}$ \\
\hline
\end{tabular}

Table 3. Recent IEEE Standards in development for smart mobility and transportations.

\begin{tabular}{|c|c|c|}
\hline Year & Title & Scope \\
\hline 2013 & $\begin{array}{l}\text { P1884 (Stray Current/Corrosion Mitigation for DC Rail Transit } \\
\text { Systems) [68] }\end{array}$ & $\begin{array}{l}\text { - Principles, methods, and data for engineering design, commissioning, installation, observing and evaluating; including mitigation and control } \\
\text { techniques for stray currents in direct current rail transit systems. }\end{array}$ \\
\hline 2013 & $\begin{array}{l}\text { P1883 (Electrical and Electro-Mechanical Bench Test Equipment (BTE) for } \\
\text { Transit Rail Projects) [69] }\end{array}$ & $\begin{array}{l}\text { - Design factors, documentation, construction materials, and the satisfactory requirement for bench test equipment for novel and current electrical and } \\
\text { electro-mechanical equipment use in transit rail systems. }\end{array}$ \\
\hline 2014 & $\begin{array}{l}\text { P2406 (Design and Construction of Non-Load Break Disconnect Switches } \\
\text { for Direct Current Applications on Transit Systems) [70] }\end{array}$ & $\begin{array}{l}\text { - Design, usage, and application of direct current non-load or no-load break disconnect switches for isolating direct current power distribution circuits in } \\
\text { transit applications. }\end{array}$ \\
\hline 2016 & P2020 (Automotive System Image Quality) [71] & $\begin{array}{l}\text { - Deals with key elements of image and quality for applications in automotive advanced driver assistance systems applications, includes recognizing } \\
\text { current metrics and alternative meaningful information associated with these elements. } \\
\text { - Formulates objective and subjective evaluation methods for measuring automotive camera image quality. } \\
\text { Presents tools and evaluation techniques to provide standards-based communication and contrast amid original equipment manufacturer and Tier } 1 \\
\text { system integrators, and component vendors concerning automotive advanced driver assistance systems image quality. }\end{array}$ \\
\hline 2017 & P2685 (Energy Storage for Stationary Engine-Starting Systems) [72] & $\begin{array}{l}\text { - Selection, installation design, sizing, installation, maintenance, and evaluating techniques for optimizing the performance and life of energy storage } \\
\text { devices and associated systems for starting stationary engines. } \\
\text { Identify when energy storage devices need replacing. Energy storage devices and related systems including (1) nickel-cadmium and lead-acid batteries; } \\
\text { (2) supercapacitors and electric double-layer capacitors; (3) air-start systems; (4) start/control battery chargers; (5) parallel battery blocking diode systems; } \\
\text { (6) monitoring systems. }\end{array}$ \\
\hline
\end{tabular}


Table 4. Recent IEEE Standards in development for smart education.

\begin{tabular}{|c|c|c|}
\hline Year & Title & Scope \\
\hline 2018 & P7919.1 (eReaders to Support Learning Applications) [73] & $\begin{array}{l}\text { - Arranges and explains the eReaders abilities for working as a platform for education, training, learning, and using other approaches for developing } \\
\text { these abilities. } \\
\text { - Methodology comprises of industry standards applications and may cover open-source reference code. }\end{array}$ \\
\hline 2019 & P2834 (Secure and Trusted Learning Systems) [74] & - Details technical specifications for privacy protection and student data management in learning online services and systems. \\
\hline 2019 & 1876 (Networked Smart Learning Objects for Online Laboratories) [75] & $\begin{array}{l}\text { - Techniques for saving, retrieving, and using online laboratories as interactive and smart learning objects. } \\
\text { - Defines techniques for combining online laboratories as smart learning objects in learning object repositories and learning environments. }\end{array}$ \\
\hline 2020 & 1589-2020 (Augmented Reality Learning Experience Model) [76] & $\begin{array}{l}\text { - Develop an overarching integrated theoretical model to identify interactivities across the real world, digital information, and the user and the conditions } \\
\text { for augmented reality-assisted learning of the environment. } \\
\text { Defines two data models and interface to Extensible Markup Language and JavaScript Object Notation for depicting learning activities and the learning } \\
\text { environment as the tasks are executed. }\end{array}$ \\
\hline
\end{tabular}

Table 5. Recent IEEE Standards in development for smart governance.

\begin{tabular}{lrll}
\hline Year & \multicolumn{1}{c}{ Title } & \multicolumn{1}{c}{ Scope } \\
\hline 2017 & P7005 (Transparent Employer Data Governance) [77] & $\begin{array}{l}\text { Methods to assist employers to validate to access, collect, share, utilize, store, and destroy employee data. } \\
\text { Specific metrics and conformance needs on (1) when handling data from trusted global partners and (2) how vendors and employers can react to } \\
\text { handling data. }\end{array}$ \\
\hline 2017 & P7004 (Child and Student Data Governance) [78] & - & Methodologies for stakeholders in certifiable and responsible student and child data governance. \\
\hline 2020 & P2145 (Framework and Definitions for Blockchain Governance) [79] & $\begin{array}{l}\text { A generic framework and nomenclature for explaining blockchain governance for all kinds of contexts and use cases, comprising of private, public, } \\
\text { permissionless, hybrid, and with permission. } \\
\text { The standard is normative concerning terminology and non-normative considering the particular blockchain systems and protocols design. }\end{array}$ \\
\hline 2020 & P2863 (Organizational Governance of Artificial Intelligence) [80] & - & $\begin{array}{l}\text { States the governance basis including safety, responsibility, accountability, transparency, and reducing bias, and procedures for performance auditing, } \\
\text { useful implementation, training, and compliance in the formulation or deployment of artificial intelligence in organizations. }\end{array}$ \\
\hline
\end{tabular}


In summary, this section has presented the need for international standards in smart city research and development. Some of the emerging standard projects are presented for various smart city domains. The next section examines the different smart cities projects worldwide and focuses on the standards examined and adopted.

\section{Smart City Pilot Projects}

Having examined the importance of international standards and the emerging ones, the following section presents some of the smart cities pilot projects from various countries. The focus is on the application of international standards. Following the alphabetical order of the continents, the smart cities pilot projects in Africa and Asia are presented in Tables 6 and 7, respectively.

Table 6. Smart cities pilot projects in Africa.

Country
Konza will be a smart city with a connected urban ICT network that provides urban services connections and
Kenya
efficient management of those services on a great scale [81]. The city will connect the following four key services:
infrastructure services including transportation, utilities, public safety and environment; citizen services including
access and participation; city services including city information, planning, and development; business services
including support services for local commerce. There is no information regarding the standards adopted in the
Konza project.
Slavova and Okwechime [82] examined the broader transformative processes taking place in Africa and
developed a vision of the future African cities. The authors showed the alignment of critical aspects of the smart city
concept with the African Union's Agenda 2063. Several factors could impact on the transformative process including:
(1) balancing the power dimension of smart city projects in Africa; (2) the dichotomy dividing rural regions from urban
spaces needs to be reduced; (3) the rapid adoption of technologies to implement a smart city. The relevant standards
were not discussed by the authors. The Stellenbosch Smart Mobility Lab helps with developing Stellenbosch to be the
first transportation leaning "Smart City" in South Africa [83]. The lab assists with the planning and implementation of
mobility applications of the Smart City model. The applications include parking for enhanced vehicle distribution,
real-time traffic and transport operations control systems, bicycle-sharing schemes, information services for
commuters, and traffic planning platforms. Transport engineers employ big data gained from probe vehicles and
human movement patterns as input into several of the aforementioned applications. There is no information regarding
the standards adopted in the Smart City model.

Table 7. Smart cities pilot projects in Asia.

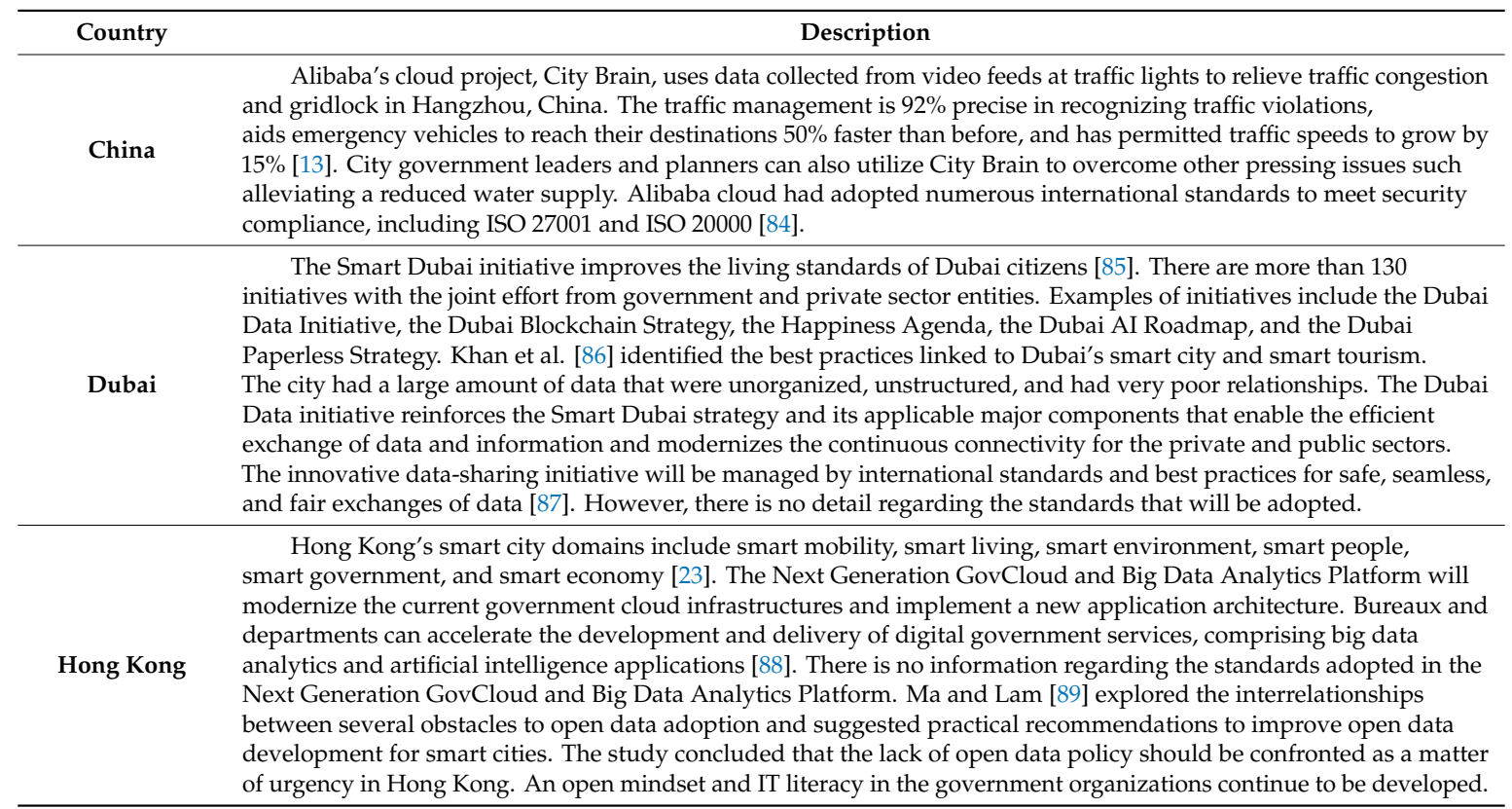


Table 7. Cont.

\begin{tabular}{|c|c|}
\hline Country & Description \\
\hline Japan & 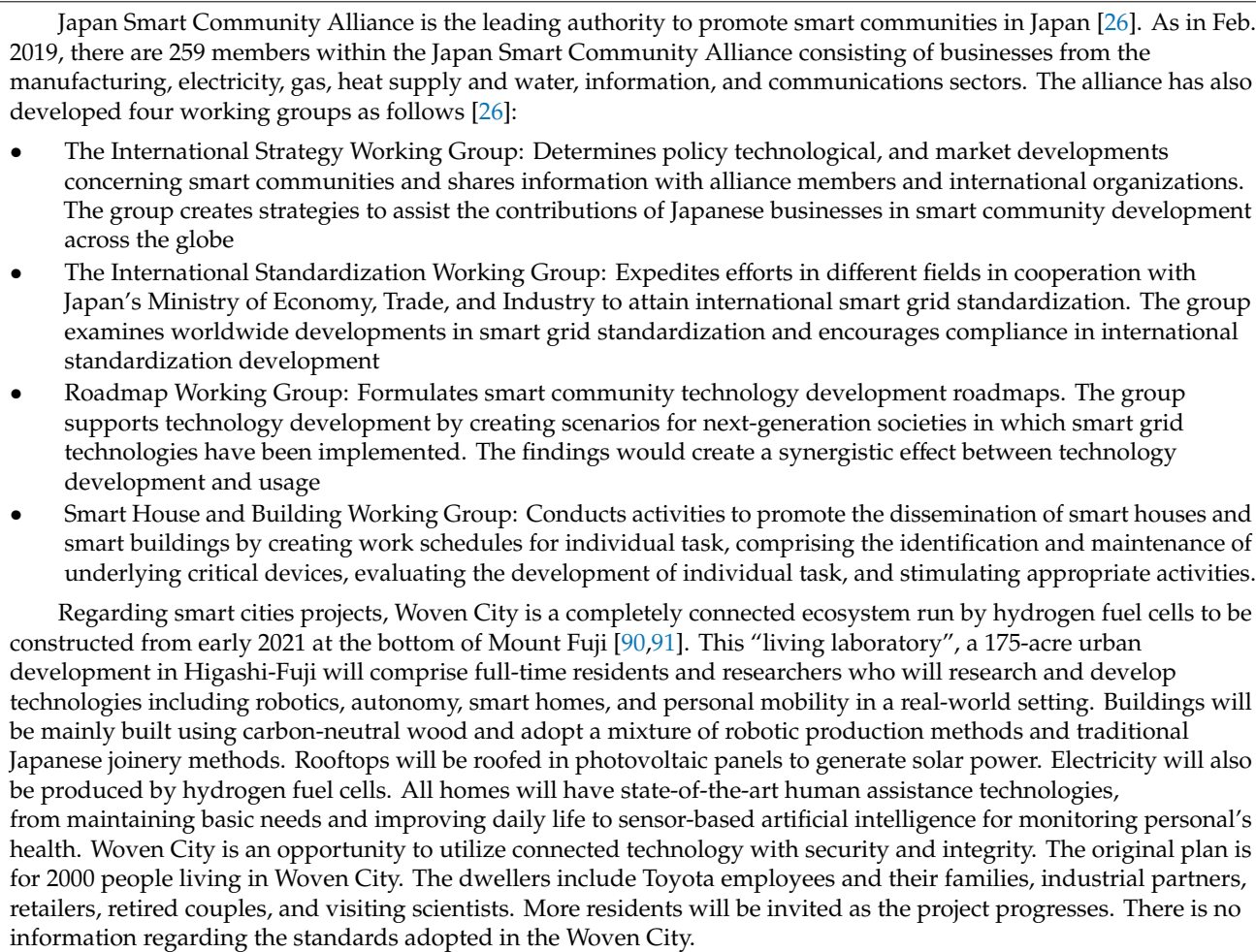 \\
\hline
\end{tabular}

In Australia, the Australian Government established the Smart Cities Plan in 2016 [92]. The Plan highlights the Government's vision for productive and habitable cities that boost innovation, upkeep growth and generate jobs. The Plan embodies a framework for a cities policy at the federal level. City Deals are the important drivers for executing the Smart Cities Plan. They are partnerships between the three levels of government and the community to strive for a shared vision for liveable and productive cities. Standards Australia is the country's leading independent, non-governmental, not-for-profit standards organization [93]. The organization is actively participating in national and international discussions on smart cities, including being involved in the ISO Technical Management Board United Nation Sustainable Development Goals Taskforce. The task force will: revisit the mapping of ISO standards to the Sustainable Development Goals; identify the importance of Sustainable Development Goals for ISO, leading to the design of a database that can be used by businesses and organizations to determine the useful standards in promoting Sustainable Development Goals; create guidance for committees on how to proactively identify the right partnerships including the United Nations and other international organizations; offer recommendations for which organizations including ISO should work in standards promotion to support Sustainable Development Goals.

The smart cities pilot projects in Europe, and North America and South America are presented in Tables 8 and 9 , respectively. 
Table 8. Smart cities pilot projects in Europe.

\begin{tabular}{|c|c|}
\hline Country & Description \\
\hline Barcelona & $\begin{array}{l}\text { Bakici et al. [94] examined the city of Barcelona and analyzed its Smart City initiative, including its urban policy } \\
\text { implications. This article analyzes Barcelona's transformation in the areas of Smart City management, drivers, } \\
\text { bottlenecks, conditions, and assets. The authors described the Barcelona Smart City model and examined the key } \\
\text { factors of the Smart City strategy while considering living labs, Open Data, e-Services, smart districts, initiatives, } \\
\text { and infrastructures. The Barcelona Smart City model consists of four domains including smart governance, } \\
\text { smart economy, smart living, and smart people. The 22@ Barcelona region is a central point for innovation and } \\
\text { economic development, as small-medium enterprises use the region as a test-bed to trial novel technologies. There is } \\
\text { no information regarding the standards adopted in the22@ Barcelona region. }\end{array}$ \\
\hline Romania & $\begin{array}{l}\text { Pop and Prostean [95] studied the implementation approaches for different smart cities in Romania. } \\
\text { The considered cities include Craiova, Napoca, Sibiu, and Timisoara. All Romanian smart cities offer mobile } \\
\text { applications to citizens to notify them in real-time of the timing for each individual public transport station. } \\
\text { In Cluj-Napoca, Craiova, and Timisoara, traffic management centers are used to monitor traffic lights. In addition, } \\
\text { parking systems are available to offer citizens to pay for parking with short message service and identify the number of } \\
\text { accessible parking places in real-time. International standards were not discussed on how the services were managed } \\
\text { and achieved. } \\
\text { The Romanian Association for Smart City [96] is the leading authority of the Smart City Industry in Romania, } \\
\text { which consists of professionals and experts from various industries. The association is also supported by over } 200 \\
\text { national and international partners. The association aims to create creative-intelligent communities in Romania and } \\
\text { achieve this by developing activities related to the Smart City ecosystem. The association has introduced } 8 \text { ISO } \\
\text { international standards in legislation, however, there are no details regarding them. } \\
\text { Alba Iulia is located in the west-central part of Romania. The pilot project Alba Iulia Smart City has many distinctive } \\
\text { features. The project promotes collaborative partnerships across governmental organizations, research institutions, } \\
\text { local administration, companies, universities, citizens, and associations. The partnerships are not driven by } \\
\text { commercial interests. The solutions are developed and examined by partner companies, with the local administration } \\
\text { providing the required support and infrastructure. It is worth mentioning that there is no technical standard discussed } \\
\text { for the Alba Iulia Smart City project [97]. }\end{array}$ \\
\hline Sweden & $\begin{array}{l}\text { Stockholm aims to achieve environmental goals and efficient cooperation between various stakeholders, } \\
\text { including the private and public sectors [98]. Kista Science City is an important venue for ICT research and } \\
\text { development. The prominent ICT businesses including IBM and Ericsson settled in Kista during the 1970s and more } \\
\text { than } 1000 \text { other ICT companies have joined. The city hosts one of the world's leading ICT clusters and largest urban } \\
\text { business districts. Robèrt [99] examined a local travel planning network in Kista Science City where the travel demand } \\
\text { is probable to surpass the capacity of the transport system in the future. There is no information regarding the } \\
\text { standards adopted in Kista Science City. }\end{array}$ \\
\hline $\begin{array}{c}\text { United } \\
\text { Kingdom }\end{array}$ & 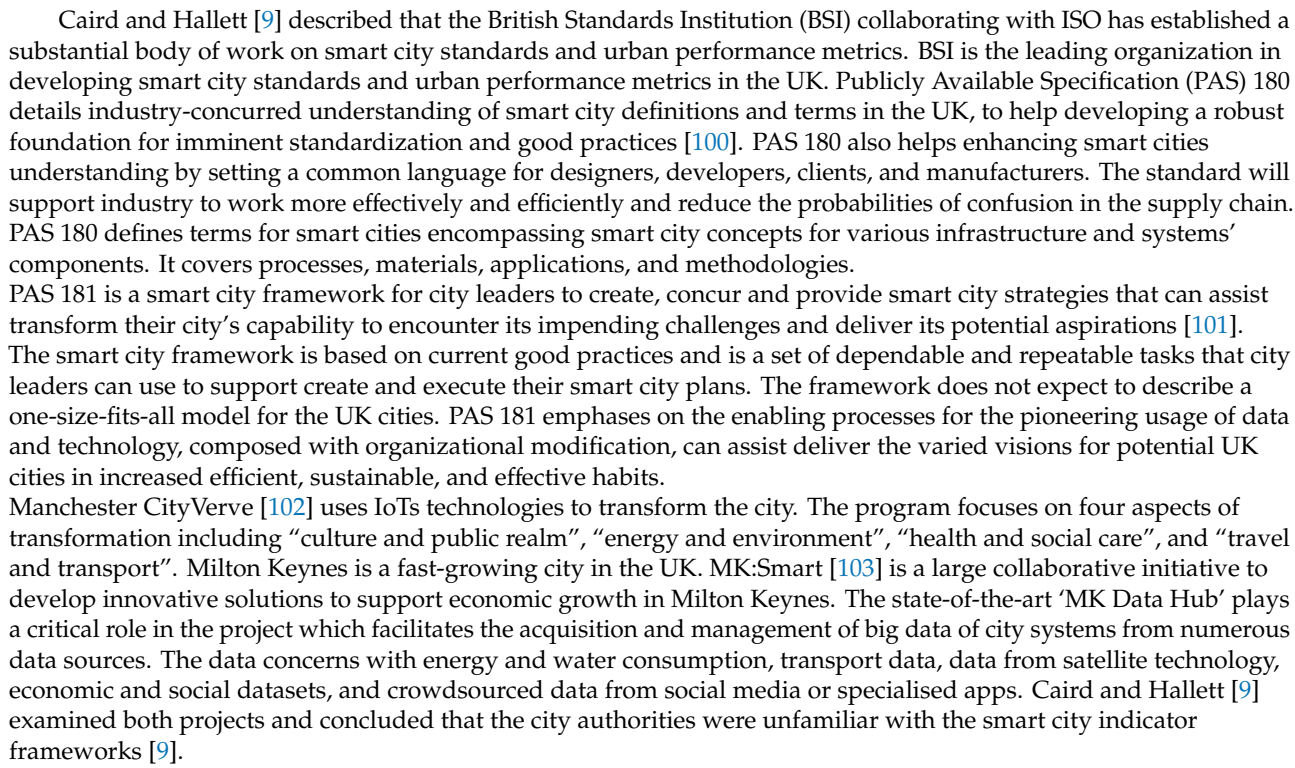 \\
\hline
\end{tabular}


Table 9. Smart cities pilot projects in North America and South America

\begin{tabular}{|c|c|}
\hline Country & Description \\
\hline Brazil & $\begin{array}{l}\text { Macke et al. [104] described that the city of Curitiba, Southern Brazil to be a green, inclusive and livable city. It is } \\
\text { the top ten smartest cities globally speaking. Curitiba has several well-known sustainability programs. } \\
\text { Effective leadership and devotion to intelligent transportation planning aided Curitiba to turn into a sustainable city } \\
\text { and a standard for effective urban planning. The city's achievements are considered in six factors namely integrated } \\
\text { urban planning, pedestrian priority zones, environmental awareness, waste management system, effective public } \\
\text { transport system, and social justice. Smart living can be attained by delivering the four factors namely, community } \\
\text { integration socio-structural relations, material well-being, and environmental well-being. International standards are } \\
\text { not discussed in the work. Afonso et al. [105] studied Brazilian capital indicators and developed a maturity model } \\
\text { called Brazilian Smart City Maturity Model to allow transform public databases into useful indicators to assist city } \\
\text { managers in planning. The authors mentioned that the ISO } 37120 \text { standard provides } 100 \text { different performance } \\
\text { indicators for cities. The standard consists of } 17 \text { themes, } 46 \text { core indicators, and } 54 \text { indicators that can help define } \\
\text { public policies based on different domains. The model is an ongoing work. }\end{array}$ \\
\hline Canada & 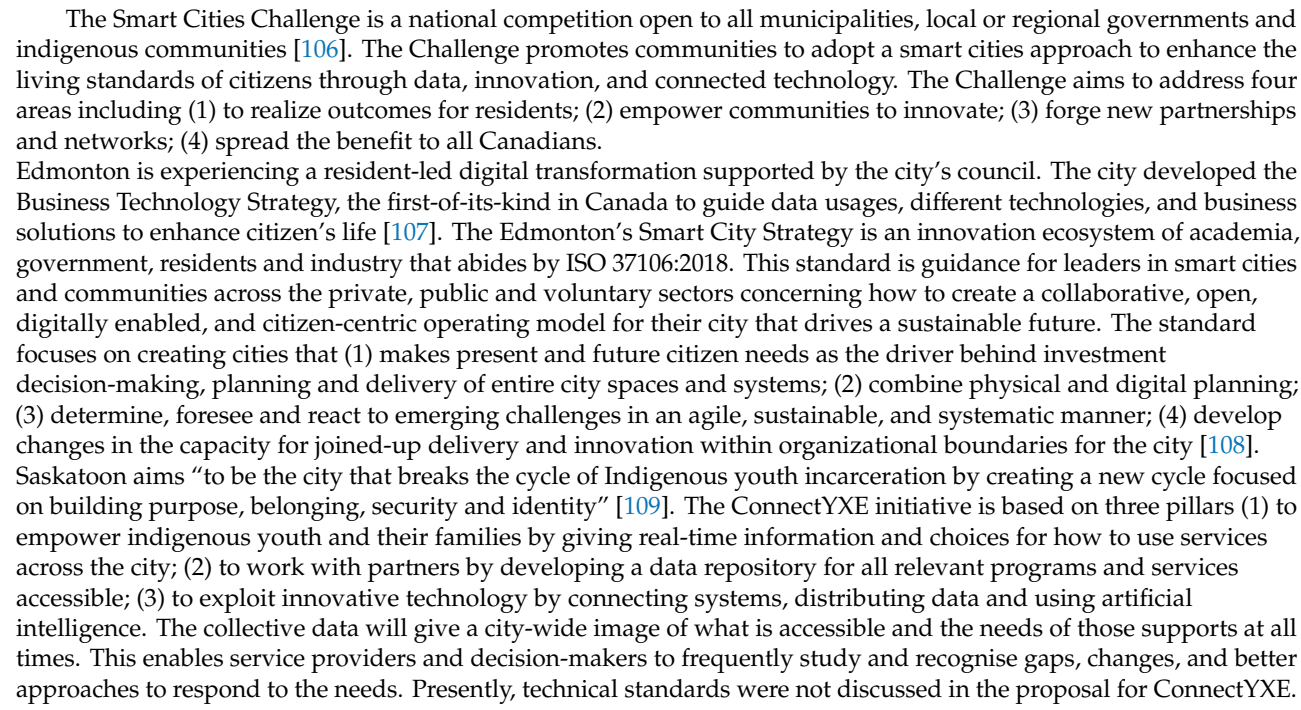 \\
\hline $\begin{array}{l}\text { United States } \\
\text { of America }\end{array}$ & $\begin{array}{l}\text { New York aims to become an equitable and smart city to improve government services and citizens living } \\
\text { standards [110]. The transformation contains multiple programs including "New York City Connected Communities", } \\
\text { where the government develops computer centers in the places with highly concentrated poverty rates. Over } 100 \\
\text { centers have been developed, which have improved the level of digital literacy and enhanced the quality of life by } \\
\text { developing employment opportunities. The digital centers are in parks, computer resource centers, New York City } \\
\text { Housing Authority Centers, recreation centers, libraries, and senior citizen centers. Another initiative is "LinkNYC" } \\
\text { developed in 2014. The purpose was to develop a free ultra-high speed WiFi network to connect the whole city with } \\
\text { free high-speed internet service. The city has installed over } 7500 \text { communication junctions with free WiFi network, } \\
\text { domestic phone calls, and cell phone charging facility. Kansas City, Missouri is one of the smartest cities due to its } \\
\text { successful technology utilization [111]. Along the two-mile track of the Kansas City Streetcar, a } 15 \text { million USD } \\
\text { public-private partnership has facilitated the placement of } 328 \text { Wi-Fi access points, } 178 \text { smart streetlights that can } \\
\text { monitor traffic patterns and available parking spaces, } 25 \text { video kiosks, pavement sensors, and video cameras. They are } \\
\text { all connected by the city's fiber-optic data network. It was determined that the three smart city projects including New } \\
\text { York City Connected Communities, LinkNYC, and the Kansas City Streetcar have not discussed technical standards. }\end{array}$ \\
\hline
\end{tabular}

In summary, the review on some smart cities developments from various countries and international standards shows:

1. There is a lack of discussions on the use of international standards in implementing smart cities. It is important to acknowledge the currently available standards in development when structuring and developing a smart city.

2. With standards and technologies are swiftly evolving, many cities need to avoid getting locked into one vendor's integrated solutions, which makes it more difficult for the city to share data with citizens, developers, and other cities.

3. International standards should be developed to address some of the most pressing challenges in a smart city, including potential solutions to a pandemic such as COVID-19 [112]. In combating COVID-19, ISO has made some standards freely available to the public, including ISO 13688:2013 (Protective clothing-General requirements) and ISO 19223:2019 (Lung ventilators and related equipment-Vocabulary and semantics) [113]. Simultaneously, IEC also decided to make some standards and most relevant normative references for critical care ventilators free of charge to 
industries who are creating products or converting their existing assembly lines to ventilator production [114]. In the current pandemic, many organizations and governments are sharing or publishing data. For example, government health agencies are publishing data concerning regional cases and deaths; symptom trackers are distributing data with researchers and making data public; technology companies are obtaining mobility data which can help us to understand the impact of the coronavirus on our lives. Standards need to support data interoperability, the ability of services and systems that create, exchange, and use data to have clear, shared expectations for the contents, context, and meaning of that data $[115,116]$.

\section{Conclusions}

Smart cities are intelligent and sustainable cities. It is well-known that a smart city requires the use of novel technologies, including robust ICT infrastructures and sensor devices. First, this paper has revisited and identified some of the new smart city definitions. The definition of a smart city is continuing to evolve, and one must accept that different terminologies exist due to the different scope considered, e.g., the region and community involved. This paper then examines the smart city from the view of international standards. It is identified that numerous international standards are currently in development to develop a smart city and the old standards are being revised to become relevant to address current society needs. Six smart city domains were identified including smart energy, smart health, smart education, smart mobility, smart economy, and smart governance. There is a need for researchers and city developers to acknowledge the different kinds of standards currently available and in development, in order to build a city that is functional and sustainable. The review identified that international standards are by no means as yet pervasive: there is a need for smart city projects to present details on the international standards adoption, and its implications for a smart city. Well-defined standards allow meaningful comparisons among smart cities implementation. With the presence of many standard bodies, challenges exist if international standards are not agreed on by standards developers and users. This paper serves as a guide on international standards for smart city researchers and developers.

Author Contributions: Conceptualization, C.S.L., Y.J., and Z.D.; formal analysis, C.S.L., Y.J., and Z.D.; resources, A.F.Z., and L.L.L.; data curation, C.S.L., and Z.D.; writing-original draft preparation, C.S.L., Y.J., Z.D., Y.T., Q.H.L.; writing-review and editing, D.W., R.T.K.W., A.F.Z., R.W., and L.L.L.; project administration, C.S.L.; funding acquisition, C.S.L., and L.L.L. All authors have read and agreed to the published version of the manuscript.

Funding: This research was funded by Brunel University London UK BRIEF Funding and the Education Department of Guangdong Province: New and Integrated Energy System Theory and Technology Research Group [Project Number 2016KCXTD022].

Acknowledgments: The authors express gratitude to the Editor-in-Chief, Patricia Luis for the invitation to contribute to the special issue entitled "Feature Papers 2020". The authors are extremely grateful to Ronghui Liu for her comments and suggestions on the work.

Conflicts of Interest: The authors declare no conflict of interest.

\section{References}

1. Smart Cities, International Electrotechnical Commission. Available online: https://www.iec.ch/smartcities/ introduction.htm (accessed on 7 August 2020).

2. Gandy, O.H., Jr.; Nemorin, S. Toward a political economy of nudge: Smart city variations. Inf. Commun. Soc. 2019, 22, 2112-2126. [CrossRef]

3. Sadowski, J.; Pasquale, F.A. The spectrum of control: A social theory of the smart city. First Monday 2015, 20. [CrossRef]

4. Inclusive Smart Cities: A European Manifesto on Citizen Engagement. Available online: https://eu-smartcities.eu/sites/default/files/2017-09/EIP-SCC\%20Manifesto\%20on\%20Citizen\% 20Engagement\%20\%26\%20Inclusive\%20Smart\%20Cities_0.pdf (accessed on 7 August 2020).

5. Ageing and Life-Course. Available online: https://www.who.int/ageing/projects/age-friendly-environments/ en (accessed on 7 August 2020). 
6. Van Zoonen, L. Privacy concerns in smart cities. Gov. Inf. Q. 2016, 33, 472-480. [CrossRef]

7. Lai, C.S.; Lai, L.L.; Lai, Q.H. Smart Grids and Big Data Analytics for Smart Cities, 1st ed.; Springer International Publishing: New York, NY, USA, 2020.

8. Camero, A.; Alba, E. Smart City and information technology: A review. Cities 2019, 93, 84-94. [CrossRef]

9. Caird, S.P.; Hallett, S.H. Towards evaluation design for smart city development. J. Urban Des. 2019, 24, 188-209. [CrossRef]

10. ISO/TR 37150:2014(en) Smart Community Infrastructures-Review of Existing Activities Relevant to Metrics. Available online: https://www.iso.org/obp/ui/\#iso:std:iso:tr:37150:ed-1:v1:en (accessed on 7 August 2020).

11. ISO/TS 37151:2015 Smart Community Infrastructures-Principles and Requirements for Performance Metrics. Available online: https://www.iso.org/standard/61057.html (accessed on 7 August 2020).

12. Citykeys. Available online: http://citykeys-project.eu (accessed on 7 August 2020).

13. Hasija, S.; Shen, Z.-J.M.; Teo, C.-P. Smart city operations: Modeling challenges and opportunities. Manuf. Serv. Oper. Manag. 2020, 22, 203-213. [CrossRef]

14. Anthopoulos, L. Smart City Emergence: Cases From Around the World; Elsevier: Amsterdam, The Netherlands, 2019.

15. van Winden, W.; van den Buuse, D. Smart city pilot projects: Exploring the dimensions and conditions of scaling up. J. Urban Technol. 2017, 24, 51-72. [CrossRef]

16. Deakin, M.; Al Waer, H. From intelligent to smart cities. Intell. Build. Int. 2011, 3, 140-152. [CrossRef]

17. Chamran, M.K.; Yau, K.-L.A.; Noor, R.; Wong, R. A Distributed Testbed for 5G Scenarios: An Experimental Study. Sensors 2020, 20, 18. [CrossRef]

18. Deakin, M. Smart Cities: Governing, Modelling and Analysing the Transition; Routledge: Oxford, UK, 2013.

19. ASEAN Smart Cities Framework. Available online: https://asean.org/storage/2019/02/ASCN-ASEAN-SmartCities-Framework.pdf (accessed on 7 August 2020).

20. Smart Cities Overview-Guide, BSI Standards Publication. Available online: http://shop.bsigroup.com/ upload/Shop/Download/PAS/30313208-PD8100-2015.pdf (accessed on 7 August 2020).

21. Department for Business Innovation \& Skills Smart Cities: Background Paper. Available online: https://assets.publishing.service.gov.uk/government/uploads/system/uploads/attachment_data/file/ 246019/bis-13-1209-smart-cities-background-paper-digital.pdf (accessed on 7 August 2020).

22. European Comission Smart Cities. Available online: https:/ec.europa.eu/info/eu-regional-andurban-development/topics/cities-and-urban-development/city-initiatives/smart-cities_en (accessed on 7 August 2020).

23. Office of the Government Chief Information Vision \& Mission. Available online: https://www.smartcity.gov. hk/vision/ (accessed on 7 August 2020).

24. IEEE Smart Cities. Available online: https://smartcities.ieee.org/images/files/pdf/IEEE_Smart_Cities-_Flyer_ Nov_2017.pdf (accessed on 7 August 2020).

25. Strategic Business Plan (SBP) SMB/6817/R, International Electrotechnical Commission. Available online: https://www.iec.ch/public/miscfiles/sbp/SYCSMARTCITIES.pdf (accessed on 7 August 2020).

26. Jpan Smart Community Alliance Smart Community Development. Available online: https://www.smartjapan.org/english/ (accessed on 7 August 2020).

27. Ministry of Housing and Urban Affairs Government of India Smart Cities Mission. Available online: http://smartcities.gov.in/content/innerpage/what-is-smart-city.php (accessed on 7 August 2020).

28. Deloitte Define Your Smart City Strategy. Available online: https://www2.deloitte.com/us/en/pages/ consulting/solutions/smart-cities-strategies.html (accessed on 7 August 2020).

29. Fedorova, E.; Caló, A.; Pongrácz, E. Balancing Socio-Efficiency and Resilience of Energy Provisioning on a Regional Level, Case Oulun Energia in Finland. Clean Technol. 2019, 1, 273-293. [CrossRef]

30. Lai, C.S.; Jia, Y.; Lai, L.L.; Xu, Z.; McCulloch, M.D.; Wong, K.P. A comprehensive review on large-scale photovoltaic system with applications of electrical energy storage. Renew. Sustain. Energy Rev. 2017. [CrossRef]

31. Xu, X.; Jia, Y.; Xu, Y.; Xu, Z.; Chai, S.; Lai, C.S. A Multi-agent Reinforcement Learning based Data-driven Method for Home Energy Management. IEEE Trans. Smart Grid 2020, 11, 3201-3211. [CrossRef]

32. Wang, D.; Wu, R.; Li, X.; Lai, C.S.; Wu, X.; Wei, J.; Xu, Y.; Wu, W.; Lai, L.L. Two-stage optimal scheduling of air conditioning resources with high photovoltaic penetrations. J. Clean. Prod. 2019. [CrossRef] 
33. Vaccaro, A.; Pisica, I.; Lai, L.L.; Zobaa, A.F. A review of enabling methodologies for information processing in smart grids. Int. J. Electr. Power Energy Syst. 2019, 107, 516-522. [CrossRef]

34. Lasi, H.; Fettke, P.; Kemper, H.-G.; Feld, T.; Hoffmann, M. Industry 4.0. Bus. Inf. Syst. Eng. 2014, 6, $239-242$. [CrossRef]

35. Dong, Z.; Lai, C.S.; He, Y.; Qi, D.; Duan, S. Hybrid dual-complementary metal-oxide-semiconductor/memristor synapse-based neural network with its applications in image super-resolution. IET Circuits Devices Syst. 2019, 13, 1241-1248. [CrossRef]

36. Dong, Z.; Lai, C.S.; Qi, D.; Xu, Z.; Li, C.; Duan, S. A general memristor-based pulse coupled neural network with variable linking coefficient for multi-focus image fusion. Neurocomputing 2018. [CrossRef]

37. Taha, A.; Wu, R.; Emeakaroha, A.; Krabicka, J. Reduction of electricity Costs in Medway NHS by inducing pro-environmental behaviour using persuasive technology. Future Cities Environ. 2018, 4, 1-10. [CrossRef]

38. Guerrero-Ibanez, J.A.; Zeadally, S.; Contreras-Castillo, J. Integration challenges of intelligent transportation systems with connected vehicle, cloud computing, and internet of things technologies. IEEE Wirel. Commun. 2015, 22, 122-128. [CrossRef]

39. Yin, J.; Su, S.; Xun, J.; Tang, T.; Liu, R. Data-driven approaches for modeling train control models: Comparison and case studies. ISA Trans. 2019. [CrossRef]

40. Hoel, T.; Mason, J. Standards for smart education-towards a development framework. Smart Learn. Environ. 2018, 5, 3. [CrossRef]

41. Giffinger, R.; Christian, F.; Hans, K.; Kalasek, R.; Pichler-Milanović, N.; Evert, M. Smart Cities: Ranking of European Mid-Sized Cities. Available online: https://ec.europa.eu/digital-agenda/en/smart-cities (accessed on 7 August 2020).

42. Hitachi Smart Water in Smart Cities. Available online: https://www.hitachi.eu/en-gb/social-innovationstories/communities/smart-water-smart-cities (accessed on 7 August 2020).

43. Hope, R.; Foster, T.; Money, A.; Rouse, M.; Money, N.; Thomas, M. Smart Water Systems, Project Report to UK Department for International Development. Available online: https://assets.publishing.service.gov.uk/media/ 57a08ab9e5274a31e000073c/SmartWaterSystems_FinalReport-Main_Reduced_April2011.pdf (accessed on 7 August 2020).

44. Case Study Summary: Smart Health. Available online: https://ec.europa.eu/growth/content/smart-health_en (accessed on 7 August 2020).

45. Smart Health Communities and the Future of Health. Available online: https://www2.deloitte.com/ content/dam/Deloitte/lu/Documents/life-sciences-health-care/lu-smart-health-communities.pdf (accessed on 7 August 2020).

46. Gov.UK $£ 1$ Million Boost for UK Smart Waste Tracking. Available online: https://www.gov.uk/government/ news/1-million-boost-for-uk-smart-waste-tracking (accessed on 7 August 2020).

47. Smart Waste Interreg Europe Innovation in Waste Management Policies. Available online: https://www. interregeurope.eu/smartwaste/ (accessed on 7 August 2020).

48. Swan, M. Blockchain: Blueprint for A New Economy; O’Reilly Media, Inc.: Sebastopol, CA, USA, 2015.

49. What Are Smart Cities? Available online: https://www.iso.org/sites/worldsmartcity/ (accessed on 7 August 2020).

50. Standards. Available online: https://www.iso.org/standards.html (accessed on 7 August 2020).

51. About the IEC. Available online: https://www.iec.ch/about/ (accessed on 7 August 2020).

52. About International Telecommunication Union (ITU). Available online: https://www.itu.int/en/about/Pages/ default.aspx (accessed on 7 August 2020).

53. World Council on City Data ISO 37120. Available online: https://www.dataforcities.org (accessed on 7 August 2020).

54. Editorial Team Standards Support Smart Cities. Available online: https://blog.iec.ch/2019/07/standardssupport-smart-cities/ (accessed on 7 August 2020).

55. Sang, Z.; Li, K. ITU-T standardisation activities on smart sustainable cities. IET Smart Cities 2019, 1, 3-9. [CrossRef]

56. IEEE Standards Association. IEEE 802®—Keeping the World Connected. Available online: https://standards. ieee.org/featured/802/index.html (accessed on 7 August 2020).

57. About IEEE Smart Cities. Available online: https://smartcities.ieee.org/about (accessed on 7 August 2020). 
58. IEEE Standards Association. P2784—Guide for the Technology and Process Framework for Planning a Smart City. Available online: https://standards.ieee.org/project/2784.html (accessed on 7 August 2020).

59. IEEE Standards Association. 1889-2018-IEEE Guide for Evaluating and Testing the Electrical Performance of Energy Saving Devices. Available online: https://standards.ieee.org/content/ieee-standards/en/standard/ 1889-2018.html (accessed on 7 August 2020).

60. IEEE Standards Association. P1922.1—Standard for a Method for Calculating Anticipated Emissions Caused by Virtual Machine Migration and Placement. Available online: https://standards.ieee.org/project/1922_1.html (accessed on 7 August 2020).

61. IEEE Standards Association. P2814-Techno-economics Metrics Standard for Hybrid Energy and Storage Systems. Available online: https://standards.ieee.org/project/2814.html (accessed on 7 August 2020).

62. IEEE Standards Association. P2852-Intelligent Assessment of Safety Risk for Overhead Transmission Lines under Multiple Operating Conditions. Available online: https://standards.ieee.org/project/2852.html (accessed on 7 August 2020).

63. IEEE Standards Association. 1708-2014-IEEE Standard for Wearable Cuffless Blood Pressure Measuring Devices. Available online: https://standards.ieee.org/standard/1708-2014.html (accessed on 7 August 2020).

64. IEEE Standards Association. P3333.2.5-Standard for Bio-CAD File Format for Medical Three-Dimensional (3D) Printing. Available online: https://standards.ieee.org/project/3333_2_5.html (accessed on 7 August 2020).

65. IEEE Standards Association. P1752—Standard for Mobile Health Data. Available online: https://standards. ieee.org/project/1752.html (accessed on 7 August 2020).

66. IEEE Standards Association. 1847-2019_IEEE Recommended Practice for Common Framework of Location Services for Healthcare. Available online: https://standards.ieee.org/standard/1847-2019.html (accessed on 7 August 2020).

67. IEEE Standards Association. P2621.1—Standard for Wireless Diabetes Device Security Assurance: Product Security Evaluation Program. Available online: https://standards.ieee.org/project/2621_1.html (accessed on 7 August 2020).

68. IEEE Standards Association. P1884-Guide for Stray Current/Corrosion Mitigation for DC Rail Transit Systems. Available online: https://standards.ieee.org/project/1884.html (accessed on 7 August 2020).

69. IEEE Standards Association. P1883-Recommended Practice for Electrical and Electro-Mechanical Bench Test Equipment (BTE) for Transit Rail Projects. Available online: https://standards.ieee.org/project/1883.html (accessed on 7 August 2020).

70. IEEE Standards Association. P2406-IEEE Draft Standard for Design and Construction of Non-Load Break Disconnect Switches for Direct Current Applications on Transit Systems. Available online: https: //standards.ieee.org/project/2406.html (accessed on 7 August 2020).

71. IEEE Standards Association. P2020—Standard for Automotive System Image Quality. Available online: https://standards.ieee.org/project/2020.html (accessed on 7 August 2020).

72. IEEE Standards Association. P2685-Recommended Practice for Energy Storage for Stationary Engine-Starting Systems. Available online: https://standards.ieee.org/project/2685.html (accessed on 7 August 2020).

73. IEEE Standards Association. P7919.1-Requirements for eReaders to Support Learning Applications. Available online: https://standards.ieee.org/project/7919_1.html (accessed on 7 August 2020).

74. IEEE Standards Association. P2834-Standard for Secure and Trusted Learning Systems. Available online: https://standards.ieee.org/project/2834.html (accessed on 7 August 2020).

75. IEEE Standards Association. 1876-2019-IEEE Standard for Networked Smart Learning Objects for Online Laboratories. Available online: https://standards.ieee.org/standard/1876--2019.html (accessed on 7 August 2020).

76. IEEE Standards Association. 1589-2020_IEEE Standard for Augmented Reality Learning Experience Model. Available online: https://standards.ieee.org/standard/1589--2020.html (accessed on 7 August 2020).

77. IEEE Standards Association. P7005—Standard for Transparent Employer Data Governance. Available online: https://standards.ieee.org/project/7005.html (accessed on 7 August 2020).

78. IEEE Standards Association. P7004-Standard for Child and Student Data Governance. Available online: https://standards.ieee.org/project/7004.html (accessed on 7 August 2020).

79. IEEE Standards Association. P2145—Standard for Framework and Definitions for Blockchain Governance. Available online: https://standards.ieee.org/project/2145.html (accessed on 7 August 2020). 
80. IEEE Standards Association. P2863-Recommended Practice for Organizational Governance of Artificial Intelligence. Available online: https://standards.ieee.org/project/2863.html (accessed on 7 August 2020).

81. SmartCity. Available online: https://www.konza.go.ke/smart-city/ (accessed on 7 August 2020).

82. Slavova, M.; Okwechime, E. African smart cities strategies for Agenda 2063. Afr. J. Manag. 2016, 2, $210-229$. [CrossRef]

83. Smart City. Available online: http://www.sun.ac.za/english/faculty/eng/ssml/research-focus/smart-city (accessed on 7 August 2020).

84. Security \& Compliance Center. Available online: https://www.alibabacloud.com/trust-center (accessed on 7 August 2020).

85. Our Vision Is to Make Dubai the Happiest City on Earth. Available online: https://www.smartdubai.ae (accessed on 7 August 2020).

86. Khan, M.S.; Woo, M.; Nam, K.; Chathoth, P.K. Smart city and smart tourism: A case of Dubai. Sustainability 2017, 9, 2279. [CrossRef]

87. Smart Dubai and Dubai Economy Launch New Data Initative for Retail Sector. Available online: https://www.smartdubai.ae/newsroom/news/smart-dubai-and-dubai-economy-launch-new-datainitiative-for-retail-sector (accessed on 7 August 2020).

88. Office of the Government Chief Information Officer The Government of the Hong Kong Special Administrative Region. Available online: https://www.ogcio.gov.hk/en/about_us/facts/doc/Fact_Sheet-OGCIO-EN.pdf (accessed on 7 August 2020).

89. Ma, R.; Lam, P.T.I. Investigating the barriers faced by stakeholders in open data development: A study on Hong Kong as a "smart city". Cities 2019, 92, 36-46. [CrossRef]

90. Toyota Woven City. Available online: https://www.woven-city.global (accessed on 7 August 2020).

91. Toyota to Build A Hydrogen-Powered City of the Future. Available online: https://blog.toyota.co.uk/toyotawoven-city-hydrogen-power (accessed on 7 August 2020).

92. Cities. Available online: https://www.infrastructure.gov.au/cities/ (accessed on 7 August 2020).

93. Smart Cities. Available online: https://www.standards.org.au/engagement-events/flagship-projects/smartcities (accessed on 7 August 2020).

94. Bakıc1, T.; Almirall, E.; Wareham, J. A smart city initiative: The case of Barcelona. J. Knowl. Econ. 2013, 4, 135-148. [CrossRef]

95. Pop, M.-D.; Proștean, O. A comparison between smart city approaches in road traffic management. Procedia Soc. Behav. Sci. 2018, 238, 29-36. [CrossRef]

96. The Romanian Association for Smart City. Available online: https://romaniansmartcity.ro (accessed on 7 August 2020).

97. World Bank Group. The City of Alba Iulia Alba Iulia Project Prioritization for 2014-2020. Available online: http://documents1.worldbank.org/curated/en/527401468190739988/pdf/Alba-Iulia-projectprioritization-for-2014-2020.pdf (accessed on 7 August 2020).

98. The Smart City. Available online: https://international.stockholm.se/city-development/the-smart-city/ (accessed on 7 August 2020).

99. Robèrt, M. Engaging private actors in transport planning to achieve future emission targets-upscaling the Climate and Economic Research in Organisations (CERO) process to regional perspectives. J. Clean. Prod. 2017, 140, 324-332. [CrossRef]

100. PAS 180 Smart Cities Vocabulary. Available online: https:/www.bsigroup.com/en-GB/smart-cities/SmartCities-Standards-and-Publication/PAS-180-smart-cities-terminology/ (accessed on 7 August 2020).

101. PAS 181 Smart City Framework. Available online: https://www.bsigroup.com/en-GB/smart-cities/SmartCities-Standards-and-Publication/PAS-181-smart-cities-framework/ (accessed on 7 August 2020).

102. What is CityVerve. Available online: https://cityverve.org.uk/what-is-cityverve/ (accessed on 7 August 2020).

103. About MKSmart. Available online: http://www.mksmart.org/about/ (accessed on 7 August 2020).

104. Macke, J.; Casagrande, R.M.; Sarate, J.A.R.; Silva, K.A. Smart city and quality of life: Citizens' perception in a Brazilian case study. J. Clean. Prod. 2018, 182, 717-726. [CrossRef]

105. Afonso, R.A.; dos Santos Brito, K.; do Nascimento, C.H.; Garcia, V.C.; Álvaro, A. Brazilian Smart Cities: Using a Maturity Model to Measure and Compare Inequality in Cities. In Proceedings of the 16th Annual International Conference on Digital Government Research; Association for Computing Machinery: New York, NY, USA, 2015; pp. 230-238. 
106. Smart Cities Challenge. Available online: https://www.infrastructure.gc.ca/cities-villes/index-eng.html (accessed on 7 August 2020).

107. Smart City Challenge Edmonton Final Proposal. Available online: https://www.edmonton.ca/city_ government/documents/CityofEdmontonSmartCitiesProposal_21MB.pdf (accessed on 7 August 2020).

108. ISO 37106:2018(en) Sustainable Cities and Communities—Guidance on Establishing Smart City Operating Models for Sustainable Communities. Available online: https://www.iso.org/obp/ui/\#iso:std:iso:37106:ed-1: v1:en (accessed on 7 August 2020).

109. Connectyxe SmartCitiesChallenge. Available online: https:/www.saskatoon.ca/sites/default/files/documents/ corporate-performance/communications/Engagement/connectyxe_saskatoon_march_5_2019.pdf (accessed on 7 August 2020).

110. The Equitable City-A New Name for New York. Available online: https://www.smartcity.press/new-yorkssmart-city-initiatives/ (accessed on 7 August 2020).

111. Smart Cities and the Journey to the "Cloud". Available online: https://www2.deloitte.com/content/ dam/Deloitte/us/Documents/about-deloitte/us-about-deloitte-smart-cities-journey-cloud.pdf (accessed on 7 August 2020).

112. Andersen, K.G.; Rambaut, A.; Lipkin, W.I.; Holmes, E.C.; Garry, R.F. The proximal origin of SARS-CoV-2. Nat. Med. 2020, 26, 450-452. [CrossRef]

113. COVID-19 Response: Freely Available ISO Standards. Available online: https://www.iso.org/covid19 (accessed on 7 August 2020).

114. Access to Key Standards for Critical Care Ventilators. Available online: https://webstore.iec.ch/webstore/ webstore.nsf/xpFAQ.xsp?OpenXPage\&id=GFOT-BNAEXA (accessed on 7 August 2020).

115. Thereaux, O. Data and Covid-19: Why Standards Matter. Available online: https://theodi.org/article/dataand-covid-19-why-standards-matter/ (accessed on 7 August 2020).

116. What is "Data Interoperability". Available online: https://datainteroperability.org (accessed on 7 August 2020).

(C) 2020 by the authors. Licensee MDPI, Basel, Switzerland. This article is an open access article distributed under the terms and conditions of the Creative Commons Attribution (CC BY) license (http://creativecommons.org/licenses/by/4.0/). 